\title{
Analysis of Factors Affecting the Amount of Credit Distribution at Credit Unions
}

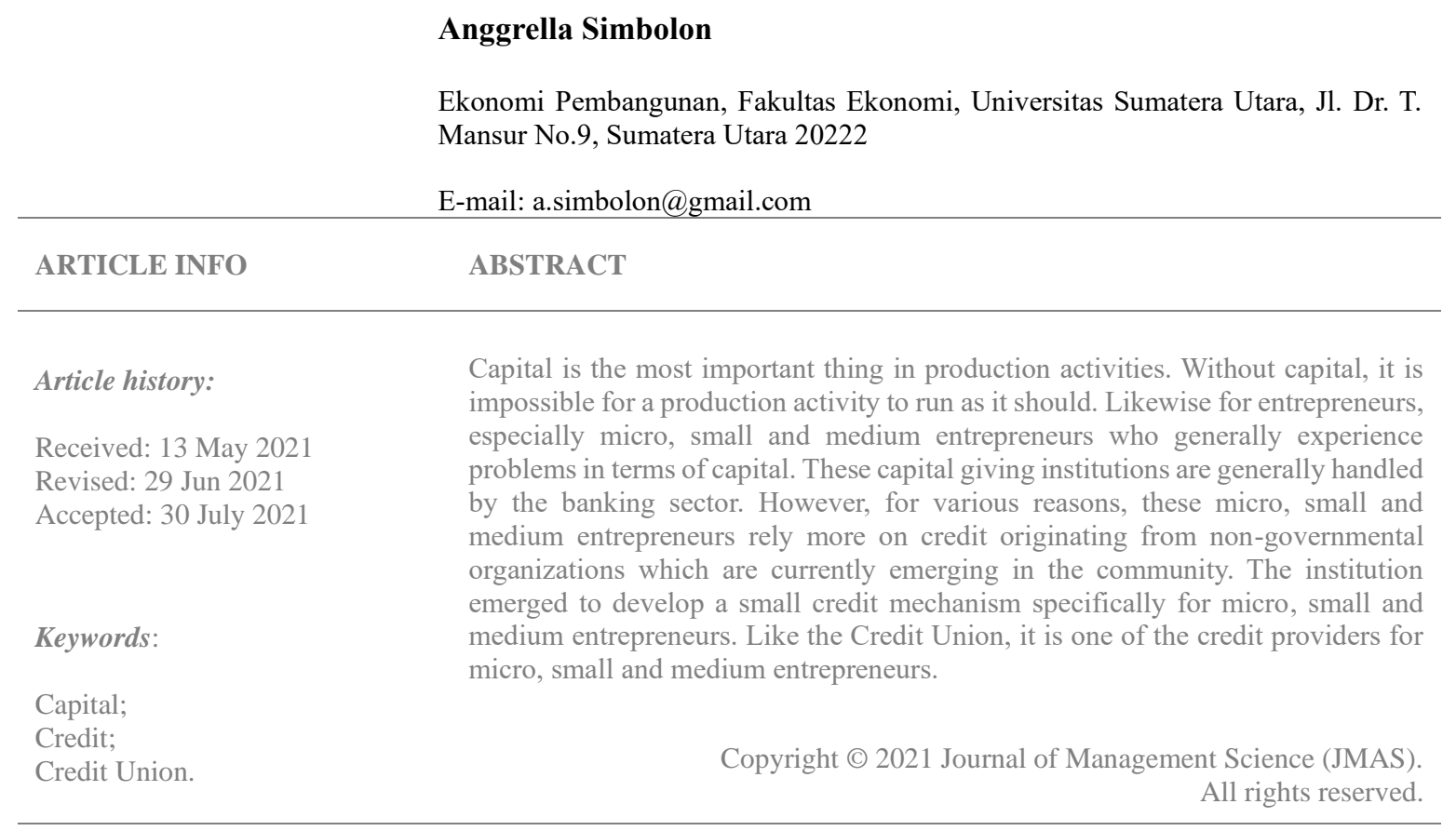

\section{Introduction}

The need for credit needs has a variety of reasons and backgrounds. Individuals, companies, countries or nations in this world have various interests and reasons to try and to get credit/loans(Ackah \& Vuvor, 2011)(Arko, 2012)(Arko, 2012). Even the government establishes agencies or institutions that are specifically tasked with distributing and providing credit so that the population or the people have the opportunity to be helped by legal sources of credit(Toulmin, 2009)(Fapohunda, 2012). In terms of these needs, the reasons and background why a party needs credit is wider and more complicated than the basic considerations of the creditor on the other hand why he gives his capital to be used as credit(Gregory, 2010)(Mizen, 2008)(Gregory, 2012). Based on the response to the problem above, the considerations credit granting, the use of credit, especially if you want to apply the credit philosophy correctly(Rona-Tas \& Hiss, 2010)(Hosna et al., 2009)(Kuhn \& Johnson, 2013). The credit philosophy is a credit agreement using a standard binding agreement between the debtor and the creditor(Provasi \& Riva, 2013)(Buchheit \& Gulati, 2010). This philosophy greatly determines the implementation of a healthy and beneficial credit for both parties(Lagat et al., 2013). So the purpose of analyzing credit needs is to observe a problem in terms of fair and healthy credit towards development people's lives in accordance with the ideals of the nation(Lagat et al., 2013)(Dearden et al., 2010).

\section{Method}

In collecting data and information on various matters concerning the number of members, number of credits, total assets, and other information related to CU, of course, obtained through research at the Cinta Mulia Credit Union itself. The type of data is in the form of primary data and secondary data. Primary data is data obtained directly from respondents, both builder/manager of Catholic college foundations and members of CU Cinta Mulia through direct interviews. Secondary data is data obtained from literature studies and official publications sourced from CU Cinta Mulia, Central Statistics Agency (BPS). Bank Indonesia (BI), and the Journal of Economics.

Collecting data is done in the following ways(Musante \& DeWalt, 2010)(Simmons et al., 2011): (a). Observation, namely direct observation to the Cinta Mulia Credit Union, especially regarding credit. (b). Interviews, namely holding questions and answers directly to employees and members. (c). Credit Union Cinta Mulia, (d). Documentation, namely notes or official documents written and issued by CU Cinta Mulia, BI, 
BPS, and other institutions that are related to this research. The first respondent is decision making at the Cinta Mulia CU Pematang Siantar. The second respondent is a customer/debtor at Cinta Mulia Credit Union. The sample to be taken is 30 people and the selection of respondents is done randomly (random sampling technique) where the total population is 15,452 people and the sample taken is $0.2 \%$ of the actual population(Gonçalves et al., 2012)(Rahmeh et al., 2008).

\section{Results and Discussion}

\section{Period 2001 to 2002 (Regional Development/Unifying Tool)}

The management for the 1997/2001 period accommodated the general public's interest in joining a credit union. In 1993 the management purchased a plot of land for the office location. In 2000, a one-story office was built and inaugurated during the 2000 Financial Year RAT held at the end of January 2001.

Table 1.CU Cinta Mulia Asset Development 2001-2009

\begin{tabular}{|c|c|c|c|c|c|}
\hline No. & Year & $\begin{array}{c}\text { Asset } \\
(\mathrm{Rp})\end{array}$ & $\begin{array}{c}\text { Save. Share } \\
(\mathrm{Rp})\end{array}$ & $\begin{array}{c}\text { Save. Non Stock } \\
(\mathrm{Rp})\end{array}$ & $\begin{array}{c}\text { Reserve } \\
(\mathrm{Rp})\end{array}$ \\
\hline 1 & 2001 & $783,104,364$ & $563,358,950$ & $26,578,584$ & $30,442.237$ \\
\hline 2 & 2002 & $2,023,962,897$ & $1,515,126,549$ & $295,604,779$ & $10,442.237$ \\
\hline 3 & 2003 & $4,836,162,824$ & $2,945,444,110$ & $1,416,624,273$ & $91,995,748$ \\
\hline 4 & 2004 & $11,918,349,137$ & $11,918,349,137$ & $5,302.148 .185$ & 181.395 .751 \\
\hline 5 & 2005 & $23,417,906,449$ & $11,031,479,577$ & $10,191,073,615$ & 393.239 .013 \\
\hline 6 & 2006 & $33,708,906,472$ & $16,388,655.017$ & $14,876,516,469$ & $537,458,433$ \\
\hline 7 & 2007 & 40.352 .824 .126 & $21,057,713,385$ & $17,141,625,081$ & $700,638,433$ \\
\hline 8 & 2008 & $47,076.156,163$ & $24,664,737,787$ & $19,301,739,277$ & $915,829,688$ \\
\hline 9 & 2009 & $49,853,802,989$ & $27,270,359,168$ & $25,738,316,191$ & $5.127 .626,431$ \\
\hline
\end{tabular}

Source: RAT CU Cinta Mulia Book 2001-2009

Table 2. Factors that encourage people to become members of CU. Noble Love Pematangsiantar

\begin{tabular}{|c|l|c|}
\hline No & \multicolumn{1}{|c|}{ Reason } & Percentage \\
\hline 1 & Good relationship with manager & $6.66 \%$ \\
\hline 2 & Good relationship with manager & $6.66 \%$ \\
\hline 3 & More satisfying service & $10 \%$ \\
\hline 4 & Ease of paying installments & $20 \%$ \\
\hline 5 & Easy management to get it & $20 \%$ \\
\hline 6 & Recommended by friends or family & $20 \%$ \\
\hline
\end{tabular}

Source: research through questionnaires

From the table above, it can be explained that the driving factors for the community to become CU members. Cinta Mulia, namely $6.66 \%$ of respondents stated that because of the good relationship with the manager, $6.66 \%$ of respondents stated that confidentiality was in the CU. Cinta Mulia is more secure, $10 \%$ of respondents stated that the service was more satisfying, $20 \%$ of respondents stated that it was easy to pay installments, $23.3 \%$ of respondents stated that it was easy to manage to get it and $33.3 \%$ of respondents stated their reasons for choosing CU. Noble love is due to the encouragement of friends or family.

Table 3.Factors Encouraging Society to Choose CU. Noble Love as a Source of Credit Financing Than Other Banks

Source: Research through questionnaires

\begin{tabular}{|c|l|c|}
\hline No & \multicolumn{1}{|c|}{ Reason } & Percentage \\
\hline 1 & Higher bank loan interest & $0 \%$ \\
\hline 2 & Do not have adequate collateral & $30 \%$ \\
\hline 3 & Availability of cheaper funds & $30 \%$ \\
\hline 4 & Banking credit matters are more difficult & $40 \%$ \\
\hline
\end{tabular}

From the table above, it can be explained that the reasons for CU members. Cinta Mulia chose CU as their source of credit financing compared to other banking loans, namely $40 \%$ of respondents stated that banking credit matters were more difficult, $30 \%$ of respondents stated that they did not have adequate collateral, and $30 \%$ of respondents stated that the availability of cheap funds was greater bank credit is $0 \%$ (none). 


\section{Conclusion}

In the last 9 years, 2001-2009, CU Cinta Mulia experienced a fairly rapid development, especially in the growth of members. With the increase in the number of members collected by the $\mathrm{CU}$, the total assets will also increase, because the amount of funds collected will increase. Rp. 662,109,305 and until 2009 there was a significant increase, namely the number of members increased to 1545 people, assets increased to Rp. 49,853,802,989 and the number of loans disbursed also increased to Rp. 44,726,176,558. Loans disbursed by CU Cinta Mulia have a positive effect on improving the standard of living of its members. The driving factor for the community to become CU members. Cinta Mulia, namely $6.66 \%$ of respondents stated that due to good relations with managers, $6.66 \%$ of respondents stated that confidentiality was in the CU. Cinta Mulia is more secure, $10 \%$ of respondents stated that the service was more satisfying, $20 \%$ of respondents stated that it was easy to pay installments, $23.3 \%$ of respondents stated that it was easy to get it and $33.3 \%$ of respondents stated their reasons for choosing CU. Noble Love as source

their credit financing compared to other banking loans, namely $40 \%$ of respondents stated that banking credit matters were more difficult, $30 \%$ of respondents stated that they did not have adequate collateral, and $30 \%$ of respondents stated that the availability of cheap funds was available.

\section{References}

Ackah, J., \& Vuvor, S. (2011). The Challenges faced by Small \& Medium Enterprises (SMEs) in Obtaining Credit in Ghana. Arko, S. K. (2012). Determining the Causes and Impact of Non Performing Loans on the Operations of Microfinance Institutions: A Case of Sinapi Aba Trust.

Buchheit, L. C., \& Gulati, G. M. (2010). Responsible sovereign lending and borrowing. Law \& Contemp. Probs., 73, 63.

Dearden, C., Goode, J., Whitfield, G., \& Cox, L. (2010). Credit and debt in low-income families.

Fapohunda, T. M. (2012). Women and the informal sector in Nigeria: Implications for development. British Journal of Arts and Social Sciences, 4(1), 35-45.

Gonçalves, I., Silva, S., Melo, J. B., \& Carreiras, J. M. B. (2012). Random sampling technique for overfitting control in genetic programming. European Conference on Genetic Programming, 218-229.

Gregory, J. (2010). Counterparty credit risk: the new challenge for global financial markets (Vol. 470). John Wiley \& Sons.

Gregory, J. (2012). Counterparty credit risk and credit value adjustment: A continuing challenge for global financial markets. John Wiley \& Sons.

Hosna, A., Manzura, B., \& Juanjuan, S. (2009). Credit risk management and profitability in commercial banks in Sweden. Rapport Nr:: Master Degree Project 2009: 36.

Kuhn, M., \& Johnson, K. (2013). Applied predictive modeling (Vol. 26). Springer.

Lagat, F. K., Mugo, R., \& Otuya, R. (2013). Effect of credit risk management practices on lending portfolio among savings and credit cooperatives in Kenya.

Mizen, P. (2008). The credit crunch of 2007-2008: a discussion of the background, market reactions, and policy responses. Federal Reserve Bank of St. Louis Review, 90(September/October 2008).

Musante, K., \& DeWalt, B. R. (2010). Participant observation: A guide for fieldworkers. Rowman Altamira.

Provasi, R., \& Riva, P. (2013). Accounting for Debt Restructuring in the Current Crisis: Italian Experience by Italian Legal Conditions. Economic Research-Ekonomska Istraživanja, 26(sup1), 244-258.

Rahmeh, O. A., Johnson, P., \& Taleb-Bendiab, A. (2008). A dynamic biased random sampling scheme for scalable and reliable grid networks. INFOCOMP Journal of Computer Science, 7(4), 1-10.

Rona-Tas, A., \& Hiss, S. (2010). The role of ratings in the subprime mortgage crisis: The art of corporate and the science of consumer credit rating. In Markets on trial: The economic sociology of the US Financial Crisis: Part A. Emerald Group Publishing Limited.

Simmons, J. P., Nelson, L. D., \& Simonsohn, U. (2011). False-positive psychology: Undisclosed flexibility in data collection and analysis allows presenting anything as significant. Psychological Science, 22(11), 1359-1366.

Toulmin, C. (2009). Securing land and property rights in sub-Saharan Africa: the role of local institutions. Land Use Policy, $26(1), 10-19$. 